\title{
TEACHING STRATEGIES FOR EFFECTIVE CONNECTION BETWEEN COLLEGE PHYSICS AND HIGH SCHOOL PHYSICS
}

\author{
Chuantao MA \\ College of Physics and Electronic Engineering \\ Taishan University, Tai'an City, China 271000
}

\begin{abstract}
College physics is a basic course that science and engineering students must learn. College physics is an advanced course based on high school physics. Physics teaching in both high school and college places an emphasis on capacity development and scientific literacy development. Teachers can adopt effective teaching strategies in the process of teaching, and do a good job of physics between college physics and high school physics, thus reducing the difficulty of students' learning and promoting the development of students' academic achievements.
\end{abstract}

Keywords- college physics, high school physics, physics teaching

\section{INTRODUCTION}

For students interested in studying science or engineering, the typical first year of college courses includes college physics and advanced mathematics. College physics is a basic course that science and engineering students who have just entered the university have come into contact with [1]. But a large proportion of students entering college in China do not meet the requirements for entrance into college-level physics. As we know, college physics and high school physics teaching have different learning tasks, different ways of thinking, different teaching objectives and teaching content. High school and colleges are different two phases, so there are different learning tasks, various thinking modes and distinct teaching objective and teaching content [2,3].

As freshmen who just enter into college, it is urgent task for them to adjust to new campus life when facing with strange environment and teaching mode. The freshmen are familiar with the past teaching mode formed in high schools, so they are used to fixing physics problems with the simple methods that they have learned in high schools. There are so many differences between the physics in these two phases, and there are much more courses and much more difficulties. Besides, physics is more abstract and complicated, compared with other subjects. Therefore, freshmen must adjust their learning methods and methods in a timely manner to quickly adapt to the teaching methods of the university [4].

The courses of college physics mainly face with the students majoring in science and engineering in institutions of universities and colleges. There are so many problems in the education of physics in high schools and colleges since a long time. The main target of high school is the college entrance examination, so people just focus on how to have a good performance and how to improve the entrance rate of students under the background of test-oriented education $[5,6]$.

The college physics teaching and the high school physics teaching are the research objects in the paper. According to the actual situation of the physics education in colleges and high schools in China, there will be further research on a series of problems, such as effective connection of physics education between these two phases.

\section{CURRENT STATUS OF PHYSICS TEACHING IN COLLEGE AND HIGH SCHOOL}

\section{A. Current Status of Physics Teaching in High School}

The situation of high school physics is very dull and dried, doing paper, having tests and entering a higher education, which has been the biggest standard for parents and teachers to measure the ability of high school students. There are so many functions in education; but the talent selection is the most important. They are divided as the excellent students and poor students through tests, and they go to different colleges and universities to participate jobs at different levels.

The major background of current education is test-oriented education. The methods in the teaching of high school physics is to master all physics knowledge to keep doing practices and papers and to keep testing. The final aim is to gain a good performance in the college entrance examination. However, quality education has been advocated now and the comprehensive development is required. There is quality extension, but it is still the test-oriented education for graduation classes. The students in the classes should learn to do practice correctly and they are just asked to know how to do experiment simply, letting alone the cultivation of the innovation ability. 
High-quality talents with all-round development of morality, intelligence, physique and beauty are cultivated in quality education, and the innovative talents should be cultivated. However, the test-oriented education has to be undertaken to distribute scarce educational resources, so that high schools' students have to face with the stress.

\section{B. Current Status of Physics Teaching in College}

Physics knowledge in college is the extension of that in high school, and there are differences in depth and breadth. The learning of college physics thinks more about logicality and there should be depth in the understanding of concepts and atmosphere, so freshmen are required to have stronger logical thinking ability to master the methods of physics learning as a whole. College students should be shaped with overall consciousness to have a better mastering of overall logicality in the learning of physics. What's more, college physics could explain a higher-level physical phenomenon. Physics is closely related with real life, so learning physics could improve the divergent thinking, abstract thinking and logical thinking in college students' life.

Logical thinking ability is very important, but the thinking is not formed groundlessly since there should be certain foundation. The root of the foundation is the connection between the college physics and high school physics. Only the connection point could be found can we have a better understanding on the meaning of divergent thinking. Through finding out the similarities and differences of these two, the connection of two parties could be built up and then the knowledge of college physics could be fixed with the thinking superior to the high schools. So that the thinking could be more abroad and the understanding on physics knowledge would be more profound. Then, there would be a better connection between these two parties. The learning of physics knowledge could affect the thinking of students from the root and students would be affected when handling some things in their life. Hence, the change of thinking would not only be important to learning and there would be also profound impact on the life.

In the college education, the lessons are less, but there are much more new posts for the rapid development of technology and the increasing need in the talent market. To adapt to the situation and improve the employment rate of colleges and universities and the target of colleges and universities to cultivate much more talents, there are many courses with strong practicability in colleges and universities. Students could choose optional courses according to their interest and the development direction in the future. The practicability is increased; however, the compulsory courses would be reduced accordingly for the optional courses since there is limitation in the courses in colleges and universities. As a result, there would be shrinkage of education to some extent. The practicability of optional courses is increased, but the traditional courses should not be ignored. The relationship between these two courses should be handled well.

\section{DIFFERENCES BETWEEN COLLEGE PHYSICS AND HIGH SCHOOL PHYSICS}

\section{A. Difference of Teaching Materials}

Teaching is course and knowledge while knowledge comes from teaching materials. Hence, the difference of high school physics and college physics is on teaching materials. In high school physics, it is divided into the optional course and compulsory course and the contents are less. There are force, heat, magnetism, light and atomic physics. The knowledge is wide but what students learn is shallow and easy. All of these are basic physics knowledge. The connection among subjects is not that large and the difficulty is less. The physics knowledge in high school is introduced from life and there are illustrations and demonstration experiments, so it is easy to understand and concrete. Students could learn it easily. There are correspondent practices in the end of each chapter and there are multiple types of practices. Most of them could be solved through formula and theorem. Hence, the difficulty in the high school physics is less, which is good to arouse the learning interest of students to increase the desire to learn. College physics is completely different. There are also force, heat, magnetism, light and atomic physics in the teaching content, but the depth and breadth are deeper than the high schools. Besides, there is great connection with other subjects, especially the higher mathematics. The solution of the physics knowledge should be solved with the formula of senior mathematics.

College physics and senior mathematics are taken at the same time, so the teaching progress is different. Sometimes, the knowledge of senior mathematics that is used to solve the physics has not been learned in the course, which increases the difficulty of college physics to some extent. The knowledge of senior mathematics is more difficult than the physics because some of them are too abstract and they are in need of demonstration and solution, so the learning of senior mathematics is also a key point. The teaching materials of college physics is introduced directly without illustration or preface, which should be boring to some extent. The contents in the teaching materials are more abstract than the high schools and the divergent thinking should be so strong. College physics focuses on theoretic reasoning, argumentation and summary with wide range of knowledge. Hence, it is easily to damage the learning initiative of freshmen if the relationship between the high school physics and college physics could not be handled well. What's more, there is certain change in the after-class practice in the teaching materials of college physics. The practices of colleges are less, and dense and multiple knowledges would be applied in one practice, which is in a feature of summary. In a word, there are huge differences on the teaching materials in college physics and high school physics [7, 8]. 


\section{B. Differences between Teaching Methods and Means}

The high school physics is relatively relaxed. Teachers would have time to have specific and detail explanation on the knowledge since there is less points and much more classes in high school physics. Hence, the teaching progress of physics is slower relatively. As a result, there should be differences in the teaching methods in these two phases. The relaxing atmosphere in the teaching of high school physics could make students have a chance to talk with teachers; and there is physics learning time in the class, so teachers would consolidate students' knowledge by doing practice, explaining practices and doing again. Teachers could have key explanation and difficulties according to the problems and mistakes of students. There is teaching with such interactive learning. After class, teachers will make some homework for students and they will check and explain homework with certain time. The knowledge could be reviewed through explanation, so that the physics knowledge system could be fixed. The teaching mean of PPT are used in the teaching of high school physics, which is more direct.

There are so different methods and means in the college physics, compared with those in high school physics. There are more contents, but the classes are less. Teachers would have no time for explanation for meeting the teaching progress, and they will make some classic practices. The ability of self-learning is the main means. The teaching methods and means of teachers of college physics is talking. There are so many knowledges in college physics, so teachers have to talk rapidly to finish the task. Hence, it is different from the high schools. Students should fully understand the knowledge lectured by teachers during the class and students need a systemic learning after class. Teachers in the class pay more attention to the theory and thinking while the teaching methods of college are only the explanation of physics knowledge points with multimedia [9].

\section{Differences of Teaching Information Feedback}

The class in high school physics is relaxing and there is time for teachers and students to have communication. Students could ask for teachers when there is something wrong. Besides, students could ask for teachers if they do not know or clarify the knowledge point. Teachers could also timely know the mastering of students, so that they could have key explanation in the class. The effective teaching information feedback could make teaching success with half effort. During the college, the communication between students and teachers is just in the class. Besides, teachers just talk about it normally, so there is no chance for students to talk with teachers. The homework made by teachers is very limited, but there is still copy in this homework, so the feedback is not fully effective.

\section{Difference of Learning Means}

The class of high school physics is very regular, doing homework after class and listening to new class in the class. There will be no review before the class and there will be no notes during the class. There is just endless homework after class, so students have to do homework, after-class practices and extracurricular practices. Students barely have their own idea and they just follow teachers, so that they could have good performance. In college, students must spend time on after-class review, and they must take notes. The learning methods and efficiency must be focused in college and the students' subjective consciousness of students must be enhanced [10].

\section{E. Differences in Learning Objectives and Targets}

It is known to us that the biggest objectives of high school students are entering colleges and universities; however, the teaching target of education is not only for it. For the opinion, students make the college entrance examination as their motivation, so they try hard to learn knowledge and to do practices and then they could gain higher performance in the score. For the objectives, the learning of students just follows the prescribed order, so it is so boring and dull with strong objective. In college, the environment is relatively relaxing, and everything is so free for freshmen. Facing with the teaching objectives of college, many students will ignore it. They just forget the original objectives for some luring and then their objectives are lower and lower, passing examination without failure and smooth graduation. Some of them have forgotten the original objectives and directions.

\section{F. Differences in Learning Psychology}

During the high school, students keep doing practice, taking all kinds of examination and quiz for the examination. The psychology of students is in a state of tension and numbness. There is not that much exams in colleges and there is only final exam. You just gain sufficient credit, which makes students in a status of stagger. Especially in the relaxing period after the college entrance examination, some college students would have idea of liberation and they just waste their time when facing with relaxing college life. The students with poor self-control would have unprecedented psychological relaxation and they take no obligations or responsibility that they should take. There is contrast between strict management of high school and the relatively free management of college, so some students are totally at loss.

\section{TEACHING STRATEGIES TO PROMOTE THE CONNECTION BETWEEN COLLEGE PHYSICS AND HIGH SCHOOL PHYSICS}

Physics teaching in both high school and college places an emphasis on capacity development and scientific literacy development. The following measures can be taken to bridge the gap between college physics and high school physics teaching.

\section{A. Improve the Teaching of the Introduction Lesson}

In the teaching process, teachers must take various methods to try to keep students in the introductory physics course so that 
they can achieve the goal of becoming physicists or engineers [1,11]. The first lesson for college is the first step of the effective connection between the high school physics and college physics. Freshmen have been familiar with the teaching mode and teaching methods of high schools, so teachers should guide the students to adjust the college study when they face with strange college life. Teachers should tell students with many differences of physics in these two phases, including what and how to learn physics. Students should be guided to build up correct view of learning and they should come to realize the learning objectives, teaching planning and testing methods of colleges, so that students could clarify the difference opinions of physics in two phases and the freshmen cold know the difference and significance of the teaching of college physics. What's more, teachers should also introduce suggestions and experiences related with physics learning, so that students could know the similarities and differences through the study of introduction and the explanation of teachers. Only by knowing the difference can students have a better understanding, and thus can they better handle the effective connection between high school physics and college physics. Teachers can demonstrate various vivid physical experiments to students and demonstrate the application of physics knowledge in daily life. Use these vivid and bizarre physical phenomena to stimulate students' interest in learning [12].

\section{B. Adjust the Progress of the Course According to the Teaching Content}

It is known to all that the teaching progress of high school is different from that of college, and students are asked to adjust to the teaching progress of college. As to freshmen, they have been familiar with that in high school, so they do take time to adjust to the progress of college. In high school, the teaching time is sufficient and there are much more courses. In addition, the physics knowledge in the high school is not that much, so teachers would have time and energy to have specific teaching, so the teaching progress is relatively slow, and freshmen are easier to accept the knowledge. However, it is different in college. The learning hours are shorter and the time for class is less, but there is much more knowledge with wider involvement, so the teaching progress of teachers should be faster. Such too fast lecturing with larger difficulties would make freshmen feel boring about the subject, which would make teaching in dilemma and decrease the passion of freshmen. Hence, teachers should adjust the progress of teaching so as to provide a buffer for freshmen to adjust the teaching in college, and then there would be effective connection between high school physics and college physics.

\section{Sufficient Teaching Content in the Class}

There is coherence in knowledge and the college physics is consolidation and improvement of high school physics. The origin of much knowledge in college could be found in high schools, which means that there is a upgrading of high school physics in the college physics. It is the reason why teachers would have review on what they have learned in the high schools in the teaching of physics, and then it is so natural to enter into the physics teaching in college. It should be noted that what freshmen learn in college is new knowledge, so the simple review and natural explanation are needed because most of atmosphere could not be explained with the knowledge in high school physics, which means that there is limitation in the teaching content in high school period to prepare for the explanation of teaching contents of college physics. So, teachers are required to have systemic understanding and knowing of high school physics. There is the basic speed, acceleration, force analysis, momentum, kinetic energy and work in the teaching materials of high school physics. It should be mentioned that teachers should know that the key of teaching materials is the new knowledge of college physics, so they should grasp the degree of review to talk the key points and connection points, instead of unrelated physics knowledge in high school. Teachers grasp the key points and do well in the effective connection between the high school physics and college physics.

\section{$D$. Effective Review of Learned Knowledge}

There are so many differences in-and-after classes of the physics in high school and college. There will be so many after-class practices since there are sufficient learning times in high school. The types of practices are basic, and the quantity is so large. According to the professional training program, the number of hours taught in college physics is often small, and the number of physical exercises is relatively small. Therefore, the questions of college physics exercises are more typical and novel, and the purpose of consolidating new knowledge is achieved through classic examples and afterschool exercises. Although the after-class practices of these two phases are different, they would share a teaching objective. Under normal situation, the physics practices in college could be solved with what freshmen have learned in high school since it should be fixed with the knowledge in college. Some of them could be answered with the knowledge in high school, but freshmen should master the physics methods of college through doing selective physics practice. On the view of the different teaching methods in college physics, there is higher requirement to freshmen, and they are asked to cultivate a habit of review, so they could adjust to the fast-pace learning progress. There is a better connection between the high school physics and college physics by with learning method of learning something new form the old knowledge.

\section{E. Cultivate the Self-learning of Freshmen}

The biggest difference of high schools and colleges is the individual subjective controllability. The teaching environment of high school is so tight that teachers and parents have arrangement before freshmen distributing their own leaning life. College is different since freshmen cultivate 
the self-control, self-control, self-study ability by themselves. Freshmen are asked to cultivate the 'self-study ability and subject consciousness in learning in the physic study. In colleges, freshmen need to learn with document. The college courses are in fast pace. It is good to have specific explanation and after-class practices in teaching material, but freshmen should study and sort out key knowledge when there are doubts or questions, so that the knowledge could be consolidated and improved. The difference in the teaching of the physics in two phases is on the sequentially. In high schools, you could find the original words of teaching content from the textbook; while college is different since teachers would have systemic explanation on the physics class for the limitation of time and learning hours. Some explanations are not in the same place, even some of them are absent in the textbook. Some long knowledge would be concluded as several words, and teachers would emphasize the knowledge for many times although it is absent in the book. So, freshmen are asked to have learning by themselves through all kinds of references so as to learn the things that are not mentioned in the books and to learn the conclusion of key knowledge. There is a full set of knowledge system and then they could know how to be integration. Through the cultivation of the self-study ability and subject consciousness of learning, there would be better connection between high school physics and college physics [13].

\section{F. Make Full Use of Information Technology as Teaching Tools}

Studies have investigated the effects of instructional guidance for simulations when guidance was provided within the learning materials or by the teachers [14]. In the high school physics class, teachers often demonstrate various intuitive physical experiments in order to give students a better understanding of physical phenomena and physical knowledge. However, it is different in colleges. The learning hours are so tight that multimedia is only used for lecturing. As to freshmen who enter into colleges, college physics is abstract, and it is hard to understand. When facing with the change of the teaching of college physics, many freshmen still depend on the teaching mode of high school and they hope to fix complicated physical atmosphere with direct thing. Hence, on the view of these, teachers should teacher with multimedia since it is more direct and real, and it is easier for the understanding of freshmen. The innovation of multimedia replacing the presentation of experiment in high school physics teaching could help freshmen to form a systemic knowledge of physics, so as to arouse the learning interest of freshmen. Then, there would be effective connection of high school physics and college physics. In the absence of equipment, virtual educational simulations potentially offer a convenient and cost-effective alternative to physical hardware. Teachers can use information technology to help students make their thinking visible $[9,15]$.

\section{CONCLUSIONS}

With the considerable shift in the educational landscape catalyzed by changes in both technological innovations and budget pressures, teachers need to adopt active engagement teaching strategies to progress physics teaching. The research of the effective connection between college physics and high school physics means so much to physics teachers. Through the research, physics teachers could have a systemic knowledge to the physics teaching in high school and college. There are force, heat, magnetism, light and atomic physics in the physics of college and high school. However, the high school's physics is relatively shallow while the college's focuses on more profound physics rules. So, there is certain guiding significance for teachers to grasp and understand physics as a whole. Currently, how to make high school students transferring to the study of college physics has been so important and it also requires freshmen to be familiar with the connection points of the physics knowledge system, so there is profound significance on the teaching of physics teachers. What's more, the research could equip teachers with full understanding on the necessity of the effective connection between the college physics and high school one. Only teachers have a full knowledge on the necessity and importance of the effective connection can they find solution to fix the freshman's inadaptability to college physics teaching, and they could find method to link with the teaching at these two phases as soon as possible. So, freshmen could adjust to the college physics teaching. The effective connection between college and high school could make the teaching easier and smooth. The cooperative and organic connection between these two teaching at two different phases could have a better teaching effect.

\section{ACKNOWLEDGEMENT}

The research is supported by the Teaching Reform Project of Taishan University (201836).

\section{REFERENCES}

[1]Mccavit, K. \& Zellner, N. E. B. (2016). Persistence of physics and engineering students via peer mentoring, active learning, and intentional advising. European Journal of Physics, vol. 37, No. 6, (pp. 065702).

[2]Benegas, J. \& Flores, J. S. (2014). Effectiveness of tutorials for introductory physics in argentinean high schools. Physical Review Special Topics - Physics Education Research, vol. 10, No. 1, (pp. 010110).

[3]Ma, C. \& Liu, T. (2016). Professional literacy structure of pre-service physics teachers in china. International Journal of Engineering Applied Sciences and Technology, vol. 1, No. 10, (pp. 1-4).

[4]Rushton, G. T., Rosengrant, D., Dewar, A., Shah, L., Ray, H. E., Sheppard, K. \& Watanabe, L. (2017). Towards a high quality high school workforce: A longitudinal, demographic analysis of U.S. Public school physics 


\section{International Journal of Engineering Applied Sciences and Technology, 2019 \\ Vol. 4, Issue 3, ISSN No. 2455-2143, Pages 62-67 \\ Published Online July 2019 in IJEAST (http://www.ijeast.com)}

teachers. Physical Review Physics Education Research, vol. 13, No. 2, (pp. 020122).

[5]Wang, J. \& Jou, M. (2016). Qualitative investigation on the views of inquiry teaching based upon the cloud learning environment of high school physics teachers from beijing, taipei, and chicago. Computers in Human Behavior, vol. 60, No., (pp. 212-222).

[6]Oberdan, T. (2015). From helmholtz to schlick: The evolution of the sign-theory of perception. Studies in History and Philosophy of Science Part A, vol. 52, (pp. 35-43).

[7]Chen, S.-C., She, H.-C., Chuang, M.-H., Wu, J.-Y., Tsai, J.-L. \& Jung, T.-P. (2014). Eye movements predict students' computer-based assessment performance of physics concepts in different presentation modalities. Computers \& Education, vol. 74, (pp. 61-72).

[8]Michalsky, T. \& Schechter, C. (2013). Preservice teachers' capacity to teach self-regulated learning: Integrating learning from problems and learning from successes. Teaching and Teacher Education, vol. 30, (pp. 60-73).

[9]Wood, B. K. \& Blevins, B. K. (2019). Substituting the practical teaching of physics with simulations for the assessment of practical skills: An experimental study. Physics Education, vol. 54, No. 3, (pp. 035004).
[10]Alonzo, A. C. \& Kim, J. (2018). Affordances of videobased professional development for supporting physics teachers' judgments about evidence of student thinking. Teaching and Teacher Education, vol. 76, (pp. 283-297).

[11]Mason, A. J. \& Singh, C. (2016). Surveying college introductory physics students' attitudes and approaches to problem solving. European Journal of Physics, vol. 37, No. 5, (pp. 055704).

[12]Jurik, V., Gröschner, A. \& Seidel, T. (2013). How student characteristics affect girls' and boys' verbal engagement in physics instruction. Learning and Instruction, vol. 23, (pp. 33-42).

[13]Venturini, P. \& Amade-Escot, C. (2014). Analysis of conditions leading to a productive disciplinary engagement during a physics lesson in a disadvantaged area school. International Journal of Educational Research, vol. 64, (pp. 170-183).

[14]Stephens, A. L. \& Clement, J. J. (2015). Use of physics simulations in whole class and small group settings: Comparative case studies. Computers \& Education, vol. 86, (pp. 137-156).

[15]Müller, T. (2014). Mpphys - a many-particle simulation package for computational physics education. Computer Physics Communications, vol. 185, No. 3, (pp. 1100-1108). 